\title{
EQUITY
}

Vol. 24, No.2, 2021, 223-242

DOI: 10.34209 /equ.v24i2.2611

P-ISSN 0216-8545 | E-ISSN 2684-9739

Diunggah : Februari 2021

Diterima : Mei 2021

Dipublikasi : Januari 2022

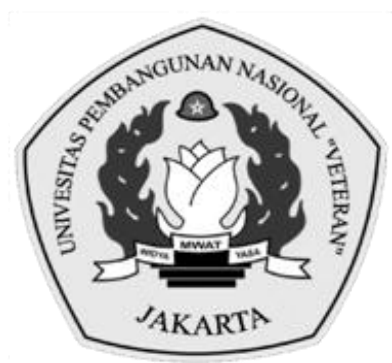

\section{EFEKTIVITAS INSENTIF PAJAK DAN PEMANFAATAN TEKNOLOGI INFORMASI TERHADAP KELANGSUNGAN UMKM DI TENGAH COVID-19}

\author{
Desi Trihastuti ${ }^{*}$, Nurul Aisyah Rachmawati ${ }^{2}$ \\ 1desitrihastuti243@gmail.com,2nurulaisyah@universitas-trilogi.ac.id \\ 1,2Universitas Trilogi, Indonesia \\ *Penulis Korespondensi
}

\begin{abstract}
Abstrak
Penelitian ini bertujuan untuk menguji pengaruh efektivitas insentif pajak dan pemanfaatan teknologi informasi terhadap kelangsungan usaha mikro, kecil dan menengah (UMKM) di tengah pandemi COVID-19. Populasi dalam penelitian ini yaitu para pelaku UMKM di DKI Jakarta. Teknik dalam pengambilan sampel yang digunakan pada penelitian ini adalah non-probability sampling dengan metode purposive sampling. Sampel pada penelitian ini adalah 124 pelaku UMKM. Metode dalam penelitian ini menggunakan penelitian kuantitatif dengan SEM (Path analysis). Hasil penelitian ini menemukan bahwa efektivitas insentif pajak dan pemanfaatan teknologi informasi berpengaruh positif dan signifikan terhadap kelangsungan UMKM di tengah pandemi COVID-19.
\end{abstract}

Kata Kunci: Insentif pajak; teknologi informasi; kelangsungan UMKM; COVID-19.

\begin{abstract}
This study aims to examine the effect of the effectiveness of tax incentives and the use of information technology on the micro, small and medium enterprises (MSMEs) sustainability in the midst of the COVID-19 pandemic. The population in this study are MSMEs in DKI Jakarta. The sampling technique used in this research is non-probability sampling with purposive sampling method. The sample in this study were 124 MSME actors. The method in this study uses quantitative research with SEM (Path analysis). The results of this study found that the effectiveness of tax incentives and the use of information technology had a positive and significant impact on the survival of MSMEs in the midst of the COVID-19 pandemic.
\end{abstract}

Keywords: Tax incentives; information technology; MSMEs sustainability; COVID-19.

\section{PENDAHULUAN}

Pandemi COVID-19 merupakan bencana nasional yang berdampak pada stabilitas ekonomi, daya beli masyarakat, serta produktivitas di kalangan masyarakat, termasuk para pelaku usaha. COVID-19 telah memberikan dampak di berbagai aspek kehidupan baik aspek sosial, ekonomi, maupun politik. Dampak ini dialami oleh seluruh masyarakat di penjuru dunia, termasuk Indonesia. Oleh sebab itu, pemerintah Indonesia memusatkan perhatian pada setiap sektor supaya bisa

Mengutip ini sebagai: Trihastuti, D, \& Rachmawati, N.A, 2020. Efektivitas Insentif Pajak Dan Pemanfaatan Teknologi Informasi Terhadap Kelangsungan Umkm Di Tengah Covid-19. Equity, 24(2), 223-242. doi.org/10.34209/equ.v24i2.2611 
menekan kekhawatiran masyarakat atas dampak virus ini. Dalam hal ini sektor ekonomi dengan kekuatan modal terbatas juga terkena imbasnya karena produktivitas masyarakat sebagai pekerja dan pelaku usaha sangat menurun.

UMKM telah menjadi bagian penting bagi suatu negara, dapat dilihat dari banyaknya jumlah pelaku usaha yang semakin berkembang di Indonesia, meskipun skala pada perekonomiannya tidak seberapa tetapi memiliki total keseluruhan UMKM yang sangat besar, bahkan sumbangan yang sudah diberikan baik kepada negara maupun masyarakat sangat besar. Seperti yang kita tahu UMKM sangat memiliki peranan yang strategis dalam perkembangan perekonomian di Indonesia. UMKM mampu berkontribusi dalam menciptakan lapangan pekerjaan, stabilitas sosial, pengurangan tingkat pengangguran dan kemiskinan serta jumlah industri yang besar sehingga sangat membantu pertumbuhan perekonomian nasional. Namun di satu sisi UMKM juga harus menghadapi berbagai permasalahan seperti kekurangan kinerja manusia yang produktif dan baik, keuangan untuk modal usaha yang terbatas, dan kurangnya pemahaman ilmu pengetahuan dan teknologi (Sudaryanto \& Hanim, 2002). Selain itu, UMKM juga memiliki berbagai resiko kegagalan yang tinggi dan rentan dalam menghadapi gejolak perekonomian (Mason, 2009).

Kutipan dari Kementerian Koperasi dan Usaha Mikro, Kecil dan Menengah, dalam dua periode terakhir yaitu 2018 dan 2019, UMKM telah berkontribusi sebesar $60.3 \%$ dan $60 \%$ dalam PDB. Penerimaan para pekerja dari UMKM sesuai dengan data Bank Indonesia periode tahun 2016 yaitu 97\%. Namun dampak yang terjadi pada masa pandemi COVID-19 menyebabkan UMKM mengalami penurunan omzet yang cukup drastis dan signifikan bahkan berpengaruh terhadap kelangsungan usaha. Kebijakan yang dilakukan oleh pemerintah seperti kebijakan Pembatasan Sosial Berskala Besar (PSBB) dengan himbauan untuk melakukan segala aktivitas dirumah saja guna mengurangi resiko dari penyebaran dan penularan COVID-19 yang berujung pada penurunan daya beli masyarakat. Beberapa UMKM berada di ambang kritis dan merugi, bahkan beberapa diantaranya harus mengalami gulung tikar karena perputaran dari modal biaya produksi yang tidak mencukupi. Akibat bencana dari COVID-19 maka perlu adanya tindakan dan upaya yang dilakukan untuk melaksanakan peraturan yang disusun dalam rangka mendukung penanggulangan dampak COVID-19.

Insentif pajak mengacu pada segala kemudahan finansial maupun non finansial yang diberikan kepada pembayar pajak oleh sistem perpajakan (Rachmawati dan Ramayanti, 2016). Tentu saja hal ini dapat memberikan keuntungan bagi wajib pajak. Berdasarkan data dari Kementerian Koperasi dan UMKM terdapat sekitar $72 \%$ dari total 60 juta UMKM yang mengalami berbagai dampak dari COVID-19 mulai dari gulung tikarnya usaha, omzet yang berkurang drastis hingga biaya produksi yang tidak memadai. Padahal UMKM memiliki kontribusi yang tinggi di dalam perekonomian nasional. Pemerintah melalui menteri keuangan akhirnya mengeluarkan Peraturan Menteri Keuangan Nomor 23 Tahun 2020 (PMK 23 Tahun 2020) tetapi Pemerintah akhirnya resmi memperluas insentif pajak untuk wajib pajak terdampak pandemi COVID-19 dengan Peraturan Menteri Keuangan Nomor 44 Tahun 2020 (PMK No. 44/PMK.03/2020) tentang kebijakan pemberian insentif pajak untuk wajib pajak terdampak COVID-19. Pada peraturan tersebut khusus untuk pelaku UMKM yang berkewajiban membayar PPh 
Final akan mendapatkan kebijakan pemberian insentif pajak penghasilan (PPh) final atau PPh bagi UMKM ditanggung oleh pemerintah (DTP). Beberapa peralihan kebijakan yang dilakukan:

Gambar 1. Peralihan Kebijakan Insentif Pajak

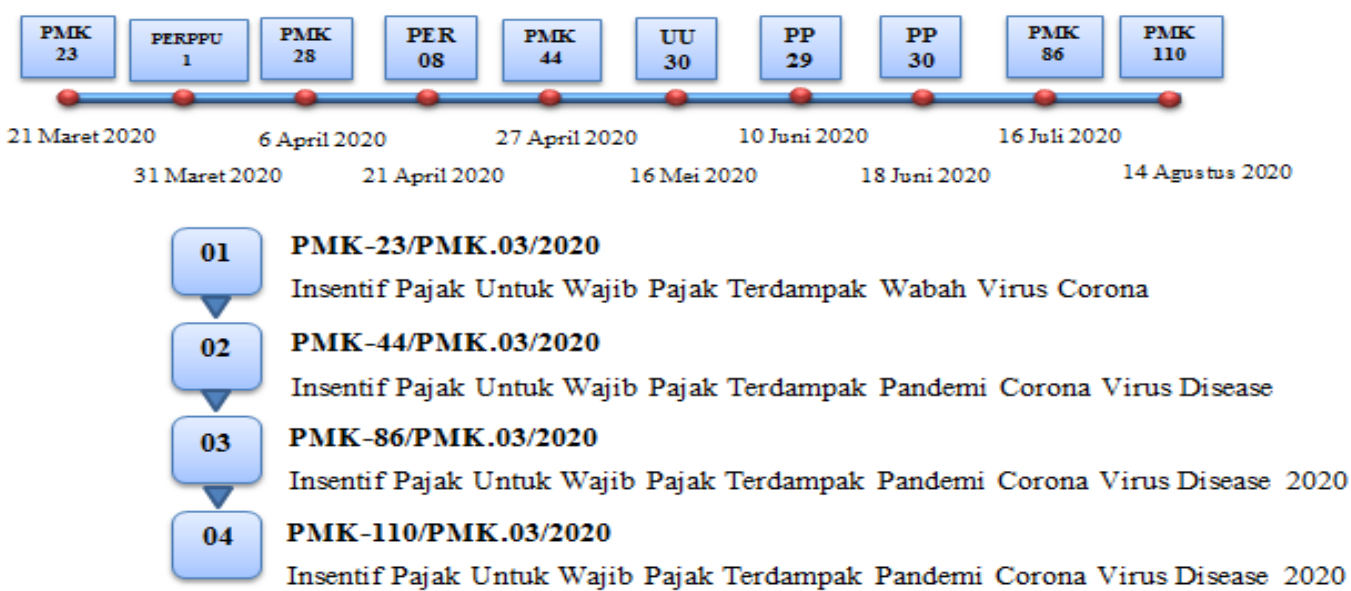

Di masa pandemi saat ini pemanfaatan teknologi informasi menjadi faktor utama dan sangat penting bagi kelangsungan kegiatan usaha di masyarakat. Pemanfaatan teknologi informasi yang dimaksimalkan dalam sektor UMKM dapat menjadi solusi agar mampu menggerakan kembali aktivitas dan produktivitas pelaku UMKM. Jika para pelaku UMKM dapat segera mengaplikasikan teknologi online dalam kegiatan usahanya maka dapat berpengaruh terhadap perekonomian yang perlahan bisa kembali meningkat. Menurut Alannita (2014), teknologi informasi dapat memberikan perubahan dalam organisasi dan proses bisnis. Perkembangan teknologi dan informasi memfasilitasi atau memberikan kemudahan dalam berbagai kegiatan di masyarakat juga memberikan berbagai masukan agar mampu memahami dan mempelajari perkembangan teknologi informasi sehingga dapat dimanfaatkan dengan benar. Peningkatan keterampilan dalam memahami dan memanfaatkan teknologi informasi di masa pandemi dapat menunjang para pelaku UMKM menjalankan kembali usahanya yang dapat dilakukan secara online.

Berdasarkan latar belakang yang telah dipaparkan di atas, penelitian ini ingin menguji tentang "Pengaruh Efektivitas Insentif Pajak Dan Pemanfaatan Teknologi Informasi Terhadap Kelangsungan UMKM Di Tengah Pandemi Coronavirus Disease 2019 (Pada UMKM DKI Jakarta)."

\section{TINJAUAN PUSTAKA}

\section{Efektivitas Insentif Pajak}

Insentif pajak atau fasilitas pajak secara umum adalah kemudahan yang diberikan oleh pemerintah kepada wajib pajak dalam hal perpajakan. Insentif pajak mengacu pada segala kemudahan finansial maupun non finansial yang diberikan kepada pembayar pajak oleh sistem perpajakan (Rachmawati dan Ramayanti, 2016). Tentu saja hal ini dapat memberikan keuntungan bagi wajib 
pajak. Terfokus pada karakteristik UMKM yang memiliki keterbatasan dalam mengikuti ketentuan perpajakan yang berlaku, maka kebijakan yang seharusnya diambil dalam hal ini yang sesuai dengan kemampuan UMKM adalah pemberian kemudahan (insentif pajak) dan penyederhanaan dalam perhitungan $\mathrm{PPh}$ final. Dalam kebijakan perpajakan bagi UMKM, maka tarif pajak yang telah ditetapkan harus sesuai dengan kemampuan UMKM agar tidak menjadi beban yang berlebihan bagi UMKM. Tujuannya, agar UMKM bisa terus berkembang dan kompetitif. COVID-19 yang saat ini sangat mengkhawatirkan bagi indonesia berdampak negatif terhadap beberapa sektor usaha, termasuk pada pelaku UMKM. Guna membantu para pelaku UMKM menjaga kelangsungan usahanya di masamasa sulit seperti ini, Dirjen Pajak memberikan fasilitas pembebasan pajak bagi pelaku UMKM. Kebijakan tersebut telah ditetapkan dalam PMK 44/PMK.03/2020.

Fasilitas pembebasan pajak tersebut diberikan oleh Direktorat Jenderal Pajak (DJP) dalam bentuk PPh Final yang menjadi tanggungan Pemerintah atas penghasilan dari usaha yang diperoleh dan diterima oleh wajib pajak (UMKM) yang terdaftar sebagai wajib pajak dan memiliki NPWP serta telah menerapkan Peraturan Pemerintah (PP) Nomor 23 Tahun 2018 PP dengan kriteria sebagai berikut:

1. Penghasilan yang diterima atau diperoleh dari usaha wajib pajak dalam negeri yang memiliki peredaran bruto tidak lebih dari Rp4.800.000.000,00 setahun, dikenai PPh yang bersifat final sebesar 0,5\% dalam jangka waktu tertentu.

2. Wajib Pajak dengan peredaran bruto tertentu yang dikenai Pajak Penghasilan bersifat final merupakan Wajib Pajak orang pribadi (WPOP) dan Wajib Pajak badan berbentuk koperasi, firma, persekutuan komanditer, atau perseroan terbatas.

Beberapa kriteria yang tidak termasuk penghasilan dari usaha yang dikenai Pajak Penghasilan bersifat final:

1. Penghasilan yang telah diterima oleh wajib pajak orang pribadi berupa jasa yang sehubungan dengan pekerjaan bebas

2. Penghasilan yang telah diterima dari luar negeri tetapi pajaknya terutang atau telah dibayarkan di luar negeri

3. Penghasilan yang telah dikenakan pajak penghasilan final tetapi dengan ketentuan peraturan perundang-undangan perpajakan tersendiri

4. Penghasilan bebas pajak

Insentif PPh Final DTP bagi UMKM merupakan bagian dari insentif dalam hal perpajakan yang diberikan kepada sektor bisnis pada tahun ini dengan dana yang dikeluarkan mencapai Rp. 123.01 triliun. Hal ini merupakan tindakan dan upaya yang dilakukan pemerintah untuk melaksanakan pengaturan dalam rangka menekan gejolak pada masyarakat atas dampak dari Pandemi Coronavirus Disease 2019.

\section{Pemanfaatan Teknologi Informasi}

Teknologi informasi sudah jadi sebuah alat yang digunakan dalam berbagai kegiatan dan sektor kehidupan selain itu juga telah memberikan pengaruh yang cukup besar terhadap tata struktur operasi ataupun manajemen pada sebuah organisasi. Teknologi informasi secara tidak langsung berpengaruh dan memiliki peranan besar dalam perkembangan bisnis online. Karena teknologi informasi ini 
bisa menemukan cara untuk belajar dan bekerja layaknya di bisnis online, cara berkomunikasi, memberikan pandangan dan informasi tentang bisnis online sehingga pelanggan dapat dengan mudah melakukan penawaran jual beli. Semakin tinggi tingkat pemanfaatan teknologi informasi maka mendukung pelaku UMKM untuk tetap menjalankan kegiatan usahanya dengan penggunaan situs penjualan, akun media sosial dan memanfaatkan layanan marketplace dapat mendukung berbagai promosi penjualan produknya, berkomunikasi dengan konsumen dan melakukan transaksi penjualan ataupun mendistribusikan produknya sehingga kegiatan usaha di masa pandemi masih dapat berlangsung tanpa adanya interaksi sosial secara langsung. Pernyataan di atas sudah didukung oleh penelitian yang pernah dilakukan sebelumnya oleh Setyaningsih Sri Utami (2010) pengaruh teknologi informasi terhadap perkembangan bisnis.

Wijana (2007) menjelaskan bahwa pemanfaatan teknologi informasi merupakan manfaat yang diharapkan dari para pengguna sistem informasi ketika menjalankan tugas atau perilaku penggunaan teknologi dalam bekerja. Menurut Wardiana (2002), teknologi informasi adalah sebuah teknologi yang digunakan untuk mengolah data, termasuk teknologi yang memperoleh, menyusun, menyimpan, memperoleh dan memanipulasi data dengan menggunakan berbagai cara untuk dapat menghasilkan informasi yang berkualitas, termasuk informasi yang relevan, akurat dan tepat waktu. Informasi ini tujuannya digunakan bagi kepentingan pribadi, bisnis dan pemerintah adalah menggunakan informasi strategis untuk pengambilan keputusan.

\section{Usaha Mikro, Kecil dan Menengah}

Berbagai kebijakan yang telah ditetapkan seperti Work From Home (WFH), Pembatasan Sosial Berskala Besar (PSBB) yang membatasi berbagai interaksi sosial dan dapat menghambat kegiatan usaha para pelaku UMKM, maka dengan memanfaatkan teknologi informasi ini mendukung pelaku UMKM untuk tetap menjalankan kegiatan usahanya dengan menggunakan situs penjualan, akun media sosial dan memanfaatkan layanan marketplace untuk melakukan berbagai promosi penjualan, berkomunikasi dengan konsumen dan melakukan transaksi penjualan ataupun mendistribusikan produknya sehingga kegiatan usaha di masa pandemi masih dapat berlangsung. Hal ini berarti dengan pemanfaatan teknologi informasi ini mampu mempertahankan kelangsungan UMKM di tengah pandemi COVID-19.

Berdasarkan Undang-Undang Nomor 20 tahun 2008 mengenai Usaha Mikro, Kecil dan Menengah yang dijelaskan sebagai berikut :

1. Usaha Mikro merupakan usaha produktif yang dimiliki oleh orang perseorangan dan/atau badan perseorangan yang telah memenuhi standar dalam usaha mikro.

2. Usaha Kecil merupakan usaha ekonomi produktif dilakukan secara mandiri, yang dijalankan oleh orang perseorangan atau badan usaha dan bukan merupakan bagian dari cabang suatu perusahaan atau anak dari salah satu perusahaan yang telah menjadi hak milik, dikendalikan atau sudah menjadi wewenang baik secara langsung atau tidak langsung dalam Usaha Menengah atau Usaha besar yang telah mengikuti standar usaha kecil.

3. Usaha Menengah merupakan sebuah kegiatan dalam ekonomi produktif dilakukan secara mandiri, dijalankan dan dilaksanakan oleh orang 
perseorangan atau oleh badan usaha dan bukan sebuah bagian dari cabang usaha atau anak dari salah satu perusahaan yang dimiliki, dikendalikan atau dikuasai atau menjadi bagian baik secara langsung atau tidak langsung dalam Usaha Menengah atau Usaha besar dengan jumlah kekayaan dan nilai aset bersih atau hasil penjualan tahunan yang sesuai dan diatur oleh undangundang ini.

\section{Efektivitas Insentif Pajak dan Kelangsungan UMKM Ditengah COVID-19}

Menurut Hasan dan Purwanto (2006: hal 232) Dalam rangka mencapai salah satu fungsi pajak yaitu fungsi mengatur (Regulasi), maka pemerintah dalam melakukan penyusunan kebijakan perpajakannya mengadakan beberapa perubahan terhadap tarif pajak yang bersifat umum dan mengeluarkan beberapa pengecualian, memberikan kemudahan atau berbagai keringan (insentif pajak) tapi bisa saja sebaliknya memberikan pemberatan khusus untuk diberlakukan kepada beberapa hal. Kebijakan insentif PPh Final yang diberikan kepada UMKM adalah fasilitas fiskal yang ditetapkan oleh pemerintah bagi wajib pajak agar mampu mendorong potensi yang dimiliki/ aktivitas dan produktivitas dari sektor UMKM. Kebijakan insentif pajak yang diberikan pemerintah yaitu insentif pajak berupa PPh Final ditanggung pemerintah memiliki tujuan untuk keberlangsungan bisnis UMKM dimana semakin efektif pemberian insentif pajak maka diharapkan dapat memberikan kemudahan dan impact positif kepada pelaku UMKM dan dapat membantu serta meningkatkan kondisi keuangan para pelaku UMKM di masa pandemi karena pajak UMKM ditanggung sepenuhnya oleh pemerintah. Hal ini juga terlihat pada penelitian dari (Mamik Indaryani, Nita Andriyani Budiman, Sri Mulyani. 2020) menunjukkan bahwa variabel pemanfaatan insentif pajak berpengaruh positif terhadap keberlangsungan usaha. Kebijakan insentif pajak dapat membantu dan meningkatkan kondisi keuangan para pelaku UMKM di masa pandemi karena pajak UMKM ditanggung sepenuhnya oleh pemerintah. Hal ini telah didukung oleh sebuah penelitian yang sebelumnya dilakukan oleh (Mamik Indaryani, Nita Andriyani Budiman, Sri Mulyani, 2020) dampak COVID-19 dan pemanfaatan insentif pajak terhadap keberlangsungan usaha pada UMKM tenun troso jepara. Dari penjelasan diatas dapat ditarik hipotesis sebagai berikut:

\section{H1: Efektivitas Insentif Pajak Berpengaruh Positif Terhadap Kelangsungan UMKM Di Tengah Pandemi COVID-19.}

\section{Pemanfaatan Teknologi Informasi dan Kelangsungan UMKM Di Era COVID-19}

Estuningsih dkk (2013) telah menyebutkan bahwa teknologi informasi sebagai proses melakukan dan mengendalikan pekerjaan organisasi sehingga tujuan bisnis dapat tercapai. Berdasarkan penelitian sebelumnya, Effendi Ishak (2005) mengemukakan bahwa kendala yang sering dihadapi pelaku UMKM adalah keterbatasan modal, pengelolaan manajemen bisnis, kesulitan dalam penetrasi dan promosi pasar, standar kualitas atau mutu produk, kesulitan dalam distribusi produk, dan belum menggunakan dan memanfaatkan teknologi informasi secara tepat. Sedangkan pada era saat ini perkembangan teknologi telah mengalami kemajuan yang sangat pesat, salah satunya adalah fasilitas internet sebagai wadah untuk melakukan transaksi jual beli secara online apalagi ditunjang dengan adanya 
media sosial yang dapat dipergunakan untuk mempromosikan produk tanpa adanya biaya.

Berdasarkan penelitian sebelumnya (Swasta Priambada, 2015) Media sosial sangat berguna dalam hal-hal berikut: 1) Untuk melakukan komunikasi yang efektif antara satu sama lain baik konsumen maupun pelaku UMKM. 2) Meningkatkan upaya pemasaran dan memperluas pangsa pasar. 3) Membantu meningkatkan pengetahuan pelaku UMKM membantu dalam pengambilan keputusan bisnis. Dalam hal ini memanfaatkan teknologi dinilai efektif dalam mempermudah dan membantu penjual dalam kegiatan usahanya dan juga meminimalkan pengeluaran biaya operasional untuk kegiatan pemasaran dan perdagangan di masa pandemi saat ini. Teknologi informasi secara tidak langsung berpengaruh dan memiliki peranan besar dalam perkembangan bisnis online. Karena teknologi informasi ini bisa menemukan cara untuk belajar dan bekerja layaknya di bisnis online, cara berkomunikasi, memberikan pandangan dan informasi tentang bisnis online sehingga pelanggan dapat dengan mudah melakukan penawaran jual beli. Hal ini didukung oleh penelitian sebelumnya dilakukan oleh (Setyaningsih Sri Utami, 2012) pengaruh teknologi informasi terhadap perkembangan bisnis. Dari penjelasan diatas dapat ditarik hipotesis sebagai berikut:

H2: Pemanfaatan Teknologi Informasi Berpengaruh Positif Terhadap Kelangsungan UMKM Di Tengah COVID-19.

\section{METODOLOGI PENELITIAN}

Pada penelitian ini sumber data yang digunakan adalah data primer. Data yang diperoleh dari penelitian ini dengan menggunakan kuesioner yang dibagikan melalui media online (google form) maupun secara langsung kepada responden. Teknik pengambilan sampel yang dilakukan dalam penelitian ini menggunakan purposive sampling, dimana unit pengambilan sampelnya dipilih berdasarkan pertimbangan dan tujuan tertentu agar memperoleh satuan sampling dengan karakteristik atau kriteria yang dibutuhkan dan sesuai dalam pengambilan sampel.

Responden pada penelitian ini adalah wajib pajak UMKM yang termasuk dalam kategori pengenaan PPh Final berdasarkan PP 23 Tahun 2018. Beberapa kriteria responden yang sesuai pada penelitian ini adalah 1) Pelaku usaha mikro, kecil, dan menengah di DKI Jakarta. 2) Memiliki toko fisik maupun toko online di DKI Jakarta. 3) Memiliki NPWP. 4) Menerapkan PP No 23 Tahun 2018. 5) Memanfaatkan insentif pajak pph final ditanggung pemerintah ( tarif $0,5 \%$ ) di masa pandemi.

Penelitian ini akan dilakukan di DKI Jakarta. Alasannya mengapa DKI Jakarta karena merupakan pusat perekonomian, selain itu penyebaran dan penularan virus corona paling banyak sehingga lebih berdampak pada para pelaku UMKM. Telah dilakukan reset penelitian di Pasar Tanah Abang dengan perizinan yang jelas dari pihak pengelola Pasar Tanah Abang dan jumlah responden yang telah mengisi kuesioner pada penelitian ini sebanyak 127 responden tapi dikarenakan ada beberapa responden yang melakukan pengisian kuesioner tidak sesuai dengan kriteria yang telah disebutkan diatas sebanyak 3 responden, dimana kriteria yang tidak sesuai tersebut adalah 1 responden memiliki omset diatas 4,8 
milyar - 50 milyar dan 2 responden tidak menerapkan PP 23 Tahun 2018 dan tidak memanfaatkan insentif pajak, maka hanya 124 yang dapat digunakan pada penelitian ini. Data diolah dan dilakukan analisis dengan menggunakan Structural Equation Modelling (SEM) dengan bantuan program Stata 14.

\section{Operasionalisasi Variabel dan Model Penelitian}

Efektivitas insentif pajak (X1)merupakan variabel independen pertama pada penelitian ini. Insentif pajak bisa dikatakan pengurangan atau pembebasan beban pajak. Pemberian insentif pajak merupakan suatu kebijakan yang diatur oleh pemerintah. Indikator yang digunakan pada pemberian insentif pajak meliputi: kemudahan dan impact positif yang ditimbulkan dari insentif pajak.

Pemanfaatan teknologi informasi (X2)merupakan variabel independen kedua pada penelitian ini. Teknologi informasi telah membawa banyak perubahan pada organisasi dan proses bisnis (Alannita, 2014). Adanya teknologi informasi pada era globalisasi diakui sebagai kebutuhan penting individu dan organisasi modern(Mahendra dan Affandy, 2013). Indikator yang digunakan dalam pemanfaatan teknologi informasi meliputi: frekuensi pemanfaatan dan media pemanfaatan.

Dalam penelitian ini, kelangsungan UMKM (X3) merupakan variabel dependen. Menurut Undang-Undang Nomor 20 Tahun 2008, UMKM diartikan sebagai usaha perdagangan yang dikelola oleh perseorangan yang mengacu pada usaha ekonomi produktif dan dilaksanakan sesuai dengan standar yang ditetapkan oleh undang-undang. Indikator yang digunakan bagi kelangsungan UMKM meliputi: pendapatan, produksi/distribusi, pemasaran dan pembiayaan.

\section{Metode Analisis}

Uji Validitas dilakukan guna mengukur ketepatan dan kecermatan pada suatu data dalam ukuran yang hendak dilakukan pengujian. Dalam uji validitas data digunakan untuk mengukur keakuratan data, sebagai alat ukur untuk suatu data yang akan diuji. Jika loading factor masing-masing indikator $>0,5$ dan nilai $p$ value $<0,05$ dinyatakan valid.

Uji reliabilitas digunakan untuk menguji apakah alat ukur yang digunakan dapat diandalkan untuk memperoleh informasi dan apakah mencerminkan informasi yang konsisten dengan fakta di tempat. Salah satu metode yang dapat digunakan untuk menguji reliabilitas kuesioner adalah Cronbach Alpha. Jika nilai Cronbach Alpha> 0,70 maka alat ukur tersebut dianggap reliabel.

Nilai F hitung pada uji signifikansi digunakan untuk menguji apakah model yang digunakan benar dan apakah hasil regresi reliabel. Uji $\mathrm{F}$ bertujuan untuk mengetahui apakah variabel independen yang digunakan dapat menjelaskan perubahan variabel dependen. Artinya nilai $\mathrm{F}$ hitung untuk membuktikan fakta atau kesalahan, menerima atau menolak hipotesis nol.

Uji hipotesis ini dilakukan dengan melihat Z- statistik dan P-value. Jika nilai Z-statistik lebih besar dari Z-tabel atau jika nilai P-Value lebih kecil dari alpha maka hipotesis terpenuhi dan begitupun sebaliknya. 


\section{HASIL DAN PEMBAHASAN}

\section{Deskriptif Statistik}

Dalam penelitian ini penulis melakukan analisis pada karakteristik responden dari data pribadi atau profil responden. Ini digunakan untuk menggambarkan apakah dengan profil responden yang berbeda memiliki penilaian yang sama atau berbeda juga. Berikut ini merupakan rincian profil responden:

Tabel 1. Deskriptif Statistik - Usia Pemilik Responden

\begin{tabular}{ccc}
\hline Keterangan & Responden & Persentase \\
\hline 20-30 tahun & 18 & $14,51 \%$ \\
31-40 tahun & 61 & $49,20 \%$ \\
41-50 tahun & 39 & $31,45 \%$ \\
$>50$ tahun & 6 & $31,45 \%$ \\
\hline & 124 & $100.00 \%$ \\
\hline
\end{tabular}

Sumber: data diolah (2020)

Tabel 1 menunjukan hasil bahwa usia 20-30 tahun sebanyak 18 responden dengan persentase 14,51\%, usia 31-40 tahun sebanyak 61 responden dengan persentase 49,20\%, usia 41-50 tahun sebanyak 39 responden dengan persentase $31,45 \%$ dan usia $>50$ tahun sebanyak 6 responden dengan persentase 4,84\%. Hal tersebut menunjukan bahwa responden pada penelitian ini paling banyak adalah responden dengan usia kisaran 31-40 tahun.

Tabel 2. Deskriptif Statistik - Jenis Usaha Responden

\begin{tabular}{lll}
\hline Keterangan & Responden & Persentase \\
\hline Jasa & 2 & $1,61 \%$ \\
Kuliner & 18 & $14,51 \%$ \\
Produksi & 11 & $8,88 \%$ \\
Retail/Pedagang Eceran & 92 & $74,20 \%$ \\
Lain-lain & 1 & $0,80 \%$ \\
\hline & 124 & $100.00 \%$ \\
\hline
\end{tabular}

Sumber: data diolah (2020)

Tabel 2 menunjukan hasil bahwa jenis usaha pelaku umkm meliputi jasa sebanyak 2 responden dengan persentase 1,61\%, dalam hal ini 2 responden dengan jenis usaha jasa ini merupakan badan usaha sehingga masih memenuhi kriteria dari penerima insentif pajak. kuliner sebanyak 18 responden dengan persentase 14,51\%, produksi sebanyak 11 responden dengan persentase $8,88 \%$, retail/Pedagang eceran sebanyak 92 responden dengan persentase $74,20 \%$ dan lain-lain sebanyak 1 responden dengan persentase 0,80\%. Hal tersebut menunjukan bahwa responden pada penelitian ini paling banyak adalah responden dengan jenis usaha retail/Pedagang eceran. 
Tabel 3. Deskriptif Statistik - Bentuk Usaha Responden

\begin{tabular}{ccc}
\hline \multicolumn{1}{c}{ Keterangan } & Responden & Persentase \\
\hline Perseorangan & 122 & $98,39 \%$ \\
Badan Usaha & 2 & $1,61 \%$ \\
\hline & 124 & $100,00 \%$ \\
\hline
\end{tabular}

Sumber : data diolah (2020)

Tabel 3 menunjukan bahwa responden pada penelitian ini lebih didominasi oleh pelaku umkm yang bentuk usahanya adalah perseorangan sebanyak 122 responden dengan persentase 98,39 dibandingkan badan usaha sebanyak 2 responden dengan persentase $1,61 \%$.

Tabel 4. Tanggapan Responden Pada Variabel Efektivitas Insentif Pajak

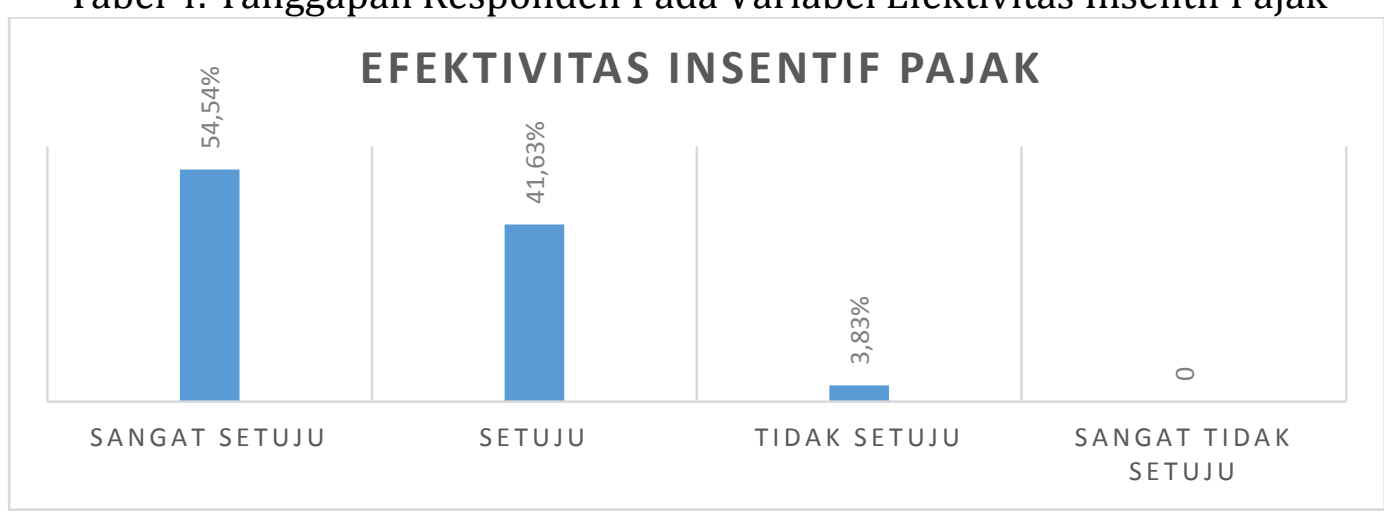

Sumber : data diolah (2020)

Menunjukan frekuensi dan proporsi tanggapan responden terhadap pernyataan pada variabel efektivitas insentif pajak sebagian besar responden menyatakan sangat setuju terhadap pernyataan tersebut sebesar 54,54\%. Dari 8 pernyataan yang diajukan kepada responden mewakili 2 indikator di dalam variabel efektivitas insentif pajak. Indikator tersebut adalah kemudahan dan impact positif yang ditimbulkan dari insentif pajak. Berarti bahwa rata-rata responden sangat setuju dengan sebuah pernyataan yang menjelaskan bahwa pemberian insentif pajak berupa PPh Final DTP ini efektif memberikan kemudahan kepada pelaku UMKM baik dalam pengajuan untuk mendapatkan insentif pajak, kemudahan dalam melaporkan pajaknya di masa pandemi saat ini dan tidak ada kendala dalam memanfaatkan insentif pajak di masa pandemi. Responden pada penelitian ini juga menyatakan sangat setuju bahwa adanya keringan pajak atau insentif pajak PPh Final DTP yang diberikan oleh pemerintah ini memberikan impact yang positif bagi para pelaku UMKM karena tidak perlu membayar beban pajaknya di masa pandemi sehingga membantu kondisi keuangan pelaku UMKM di masa pandemi COVID-19. Adanya insentif pajak PPh Final DTP sangat efektif membantu pelaku UMKM untuk mempertahankan kelangsungan usahanya di kondisi sulit akibat pandemi COVID-19, selain itu mendukung usaha para pelaku UMKM yang terdampak oleh pandemi ini dan juga dapat meningkatkan kesadaran para pelaku UMKM dalam memenuhi kewajiban perpajakannya. 
Tabel 5. Tanggapan Responden Pada Variabel Pemanfaatan Teknologi Informasi

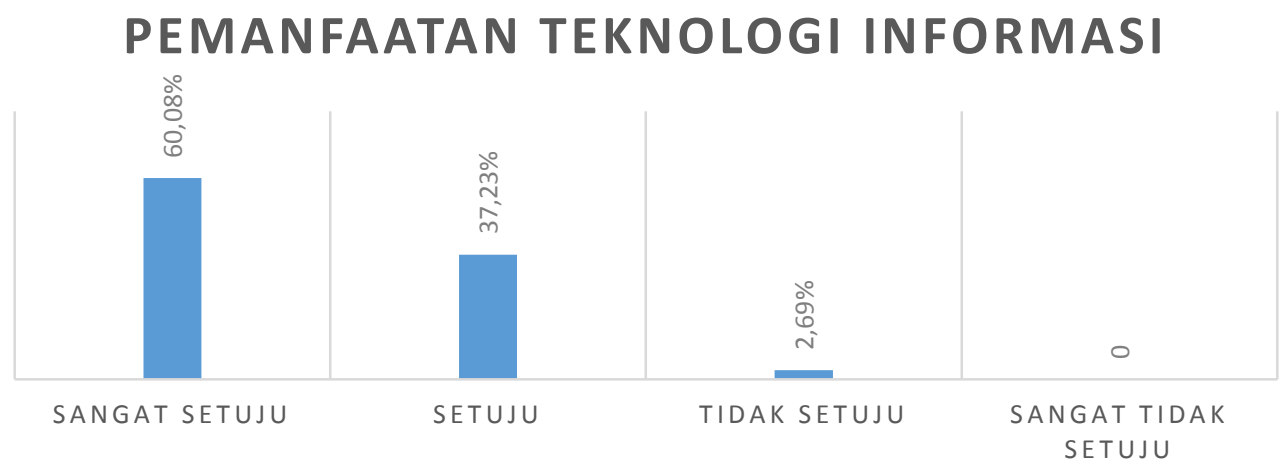

Sumber: data diolah (2020)

Menunjukan frekuensi dan proporsi tanggapan responden terhadap pernyataan pada variabel pemanfaatan teknologi informasi. Sebagian besar responden menyatakan sangat setuju terhadap pernyataan tersebut sebesar 60,08\%. Dari 6 pernyataan yang diajukan kepada responden mewakili 2 indikator di dalam variabel pemanfaatan teknologi informasi. Indikator tersebut adalah frekuensi pemanfaatan dan media pemanfaatan. Data diatas dapat diartikan bahwa sebagian besar responden sangat setuju atas pernyataan kuesioner bahwa di masa pandemi saat ini para pelaku UMKM memanfaatkan teknologi informasi pada setiap kegiatan usahanya dilihat dari frekuensi pemanfaatannya dimana pelaku UMKM sering memanfaatkan teknologi informasi dalam menjalankan kegiatan usahanya, sering menggunakan alat elektronik untuk menjalankan kegiatan usahanya dan sering menggunakan internet guna mendukung kegiatan usahanya. Pelaku UMKM juga menggunakan berbagai media pemanfaatan teknologi informasi seperti memiliki akun media sosial, memiliki situs penjualan dan memanfaatkan berbagai layanan marketplace untuk melakukan berbagai promosi produknya, berkomunikasi dengan konsumen dan melakukan berbagai transaksi penjualan tanpa harus berinteraksi secara langsung, hal ini sangat mendukung di kondisi pandemi COVID-19.

Tabel 6. Tanggapan Responden Pada Variabel Kelangsungan UMKM Di Tengah Pandemi COVID-19

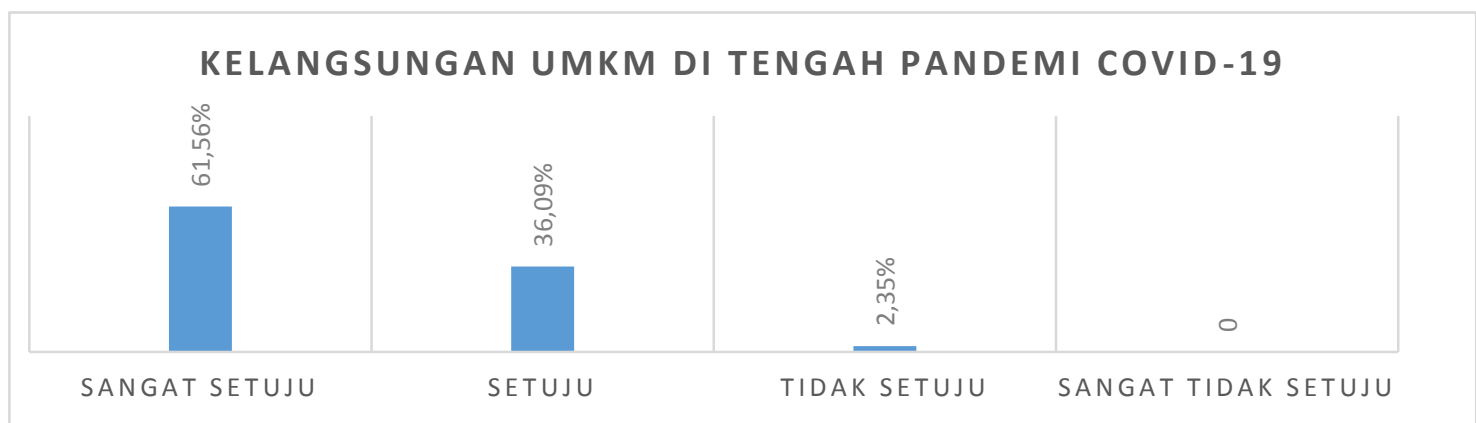

Sumber: data diolah (2020) 
Menunjukan frekuensi dan proporsi tanggapan responden terhadap pernyataan pada variabel kelangsungan umkm di tengah pandemi COVID-19. Sebagian besar responden menyatakan sangat setuju terhadap pernyataan tersebut sebesar 61,56\%. Dari 12 pernyataan yang diajukan kepada responden mewakili 4 indikator di dalam variabel kelangsungan umkm di tengah pandemi COVID-19. Indikator tersebut adalah pendapatan, produksi/distribusi, pemasaran dan pembiayaan. Artinya bahwa mayoritas responden pada penelitian ini atau pelaku UMKM dengan jenis usaha meliputi jasa, produksi, kuliner, dan pedagang eceran sangat setuju dengan pernyataan bahwa para pelaku UMKM masih menerima pendapatan di masa pandemi saat ini, masih melakukan produksi/distribusi secara rutin walaupun dengan jumlah yang kecil, masih melakukan pemasaran dan masih dapat melakukan pembayaran seperti membayar biaya tenaga kerja dan masih bisa membeli bahan baku walaupun mengurangi jumlah pembeliannya di situasi sulit pandemi akibat COVID-19.

\section{Uji Validitas}

Tabel 7. Hasil Pengujian Validitas Setelah Reduksi

\begin{tabular}{|c|c|c|c|c|}
\hline No & Variabel & & $\begin{array}{l}\text { Loading } \\
\text { Factor }\end{array}$ & Keterangan \\
\hline 1 & \multirow{8}{*}{$\begin{array}{l}\text { Kelangsungan } \\
\text { UMKM }\end{array}$} & KU4 & 0,51 & Valid \\
\hline 2 & & KU6 & 0,84 & Valid \\
\hline 3 & & KU7 & 0,73 & Valid \\
\hline 4 & & KU8 & 0,80 & Valid \\
\hline 5 & & KU9 & 0,57 & Valid \\
\hline 6 & & KU10 & 0,60 & Valid \\
\hline 7 & & KU11 & 0,71 & Valid \\
\hline 8 & & KU12 & 0,68 & Valid \\
\hline 1 & \multirow{8}{*}{$\begin{array}{l}\text { Efektivitas } \\
\text { Insentif Pajak }\end{array}$} & EIP1 & 0,64 & Valid \\
\hline 2 & & EIP2 & 0,75 & Valid \\
\hline 3 & & EIP3 & 0,67 & Valid \\
\hline 4 & & EIP4 & 0,60 & Valid \\
\hline 5 & & EIP5 & 0,65 & Valid \\
\hline 6 & & EIP6 & 0,74 & Valid \\
\hline 7 & & EIP7 & 0,65 & Valid \\
\hline 8 & & EIP8 & 0,68 & Valid \\
\hline 1 & \multirow{5}{*}{$\begin{array}{c}\text { Pemanfaatan } \\
\text { Teknologi } \\
\text { Informasi }\end{array}$} & PTI1 & 0,91 & Valid \\
\hline 2 & & PTI2 & 0,72 & Valid \\
\hline 3 & & PTI3 & 0,77 & Valid \\
\hline 4 & & PTI4 & 0,63 & Valid \\
\hline 5 & & PTI5 & 0,59 & Valid \\
\hline
\end{tabular}

Sumber: data diolah (2020)

Uji validitas adalah sebuah ukuran yang dapat menunjukan kevalidan suatu alat atau instrumen. Instrumen bisa dikatakan valid jika memperoleh suatu data yang valid (Ghazali, 2011). Efektivitas berkaitan dengan tingkat atau akuratnya 
pengukuran atas alat atau instrumen yang harus diukur. Karena indikatornya multidimensi maka akan dilakukan uji validitas pada setiap variabel laten untuk melihat dan mengamati loading faktor dari hubungan di antara observed variable dan latent variable. Dalam hal ini kriteria pada pengujian validitas ini adalah indikator pada setiap variabel dapat dinyatakan valid dan akurat apabila loading factor pada penelitian yang dihasilkan yaitu $\geq 0,50$.

Diketahui terdapat 26 indikator pernyataan dari 3 variabel, setelah dilakukan uji validitas, dari beberapa indikator pernyataan didapatkan bila nilai pada loading factor penelitian ini $\leq 0.50$ dibawah standar pengujian. Maka indikator pada kuesioner tersebut dapat dinyatakan tidak akurat atau tidak valid. Menurut Haryono, 2016 menyatakan Jika ada beberapa indikator pernyataan pada sebuah kuesioner yang tidak atau belum valid maka akan adanya pengurangan atau harus di hapus (dropped). Kemudian, dari indikator pernyataan yang telah dikatakan tidak valid maka harus dibuang atau dihilangkan.

Jika sudah dilakukan beberapa tahap pengurangan pada indikator pernyataan kuesioner, ternyata semua indikator tersebut dapat dinyatakan valid. Dari 26 indikator pernyataan tersisa 21 indikator pernyataan yang ditunjukan oleh nilai pada loading factor yang diperoleh dari seluruh indikator kuesioner tersebut $\geq 0,50$. Dengan begitu, dapat dikatakan bahwa keseluruhan indikator yang telah diuji dapat mengukur variabel pengukurnya atau latennya, maka seluruh pernyataan pada kuesioner dalam penelitian ini sudah mampu mengungkapkan apa yang akan diukur.

\section{Uji Reliabilitas}

Uji Reliabilitas yaitu menguji konsistensi dari sebuah kuesioner sehingga dapat dilakukan untuk mengukur stabilisasi kuesioner bila dilakukan dari waktu ke waktu atau secara berkelanjutan (Ghazali, 2011). Berdasarkan hasil output diperoleh hasil untuk keseluruhan variabel dalam kuesionernya yaitu dapat dinyatakan reliabel. Hal ini karena dilihat dari nilai Cronbach Alpha pada keseluruhannya $>0,70$, maka perayataan-pernyataan yang telah digunakan untuk mengukur setiap variabel - variabel tersebut dinyatakan reliabel. Berikut adalah hasil uji reliabilitas: 
Tabel 8. Hasil Pengujian Reliabilitas Setelah Reduksi

\begin{tabular}{|c|c|c|c|c|}
\hline No & Variabel & & $\begin{array}{c}\text { Cronbach } \\
\text { Alpha }\end{array}$ & Keterangan \\
\hline 1 & \multirow{8}{*}{$\begin{array}{l}\text { Kelangsungan } \\
\text { UMKM }\end{array}$} & KU4 & 0,89 & Reliabel \\
\hline 2 & & KU6 & 0,86 & Reliabel \\
\hline 3 & & KU7 & 0,87 & Reliabel \\
\hline 4 & & KU8 & 0,86 & Reliabel \\
\hline 5 & & KU9 & 0,88 & Reliabel \\
\hline 6 & & KU10 & 0,88 & Reliabel \\
\hline 7 & & KU11 & 0,87 & Reliabel \\
\hline 8 & & KU12 & 0,87 & Reliabel \\
\hline 1 & \multirow{8}{*}{$\begin{array}{c}\text { Efektivitas } \\
\text { Insentif Pajak }\end{array}$} & EIP1 & 0,85 & Reliabel \\
\hline 2 & & EIP2 & 0,84 & Reliabel \\
\hline 3 & & EIP3 & 0,85 & Reliabel \\
\hline 4 & & EIP4 & 0,86 & Reliabel \\
\hline 5 & & EIP5 & 0,85 & Reliabel \\
\hline 6 & & EIP6 & 0,84 & Reliabel \\
\hline 7 & & EIP7 & 0,85 & Reliabel \\
\hline 8 & & EIP8 & 0,85 & Reliabel \\
\hline 1 & \multirow{5}{*}{$\begin{array}{l}\text { Pemanfaatan } \\
\text { Teknologi } \\
\text { Informasi }\end{array}$} & PTI1 & 0,78 & Reliabel \\
\hline 2 & & PTI2 & 0,81 & Reliabel \\
\hline 3 & & PTI3 & 0,82 & Reliabel \\
\hline 4 & & PTI4 & 0,82 & Reliabel \\
\hline 5 & & PTI5 & 0,84 & Reliabel \\
\hline
\end{tabular}

Sumber: data diolah (2020)

Hasil uji reliabilitas menunjukkan dengan menggunakan Cronbach Alpha > 0.70 artinya telah mencapai batas yang dapat diterima. Oleh karena itu, semua indikator pernyataan untuk setiap variabel efektivitas insentif pajak, pemanfaatan teknologi informasi dan kelangsungan UMKM di tengah pandemi COVID-19 dapat diandalkan, Setiap indikator pernyataan dapat dinyatakan reliabel. Dapat disimpulkan bahwa setiap penyataan pada operasional pengukuran variabel penelitian ini sudah konsisten dan stabil.

\section{Model Struktural (Structural Model)}

Dalam model SEM, model pengukuran dan model parameter struktural diperkirakan secara bersama-sama dan harus memenuhi persyaratan atau kebijakan sesuai dengan tuntutan fit model, maka model harus didasarkan pada teori atau materi yang kuat dan mendalam. Hasil dari perkiraan dan fit model one step approach to SEM dibantu dengan program Stata 14. Hasil dari pengujian ini dapat diperhatikan dibawah ini: 


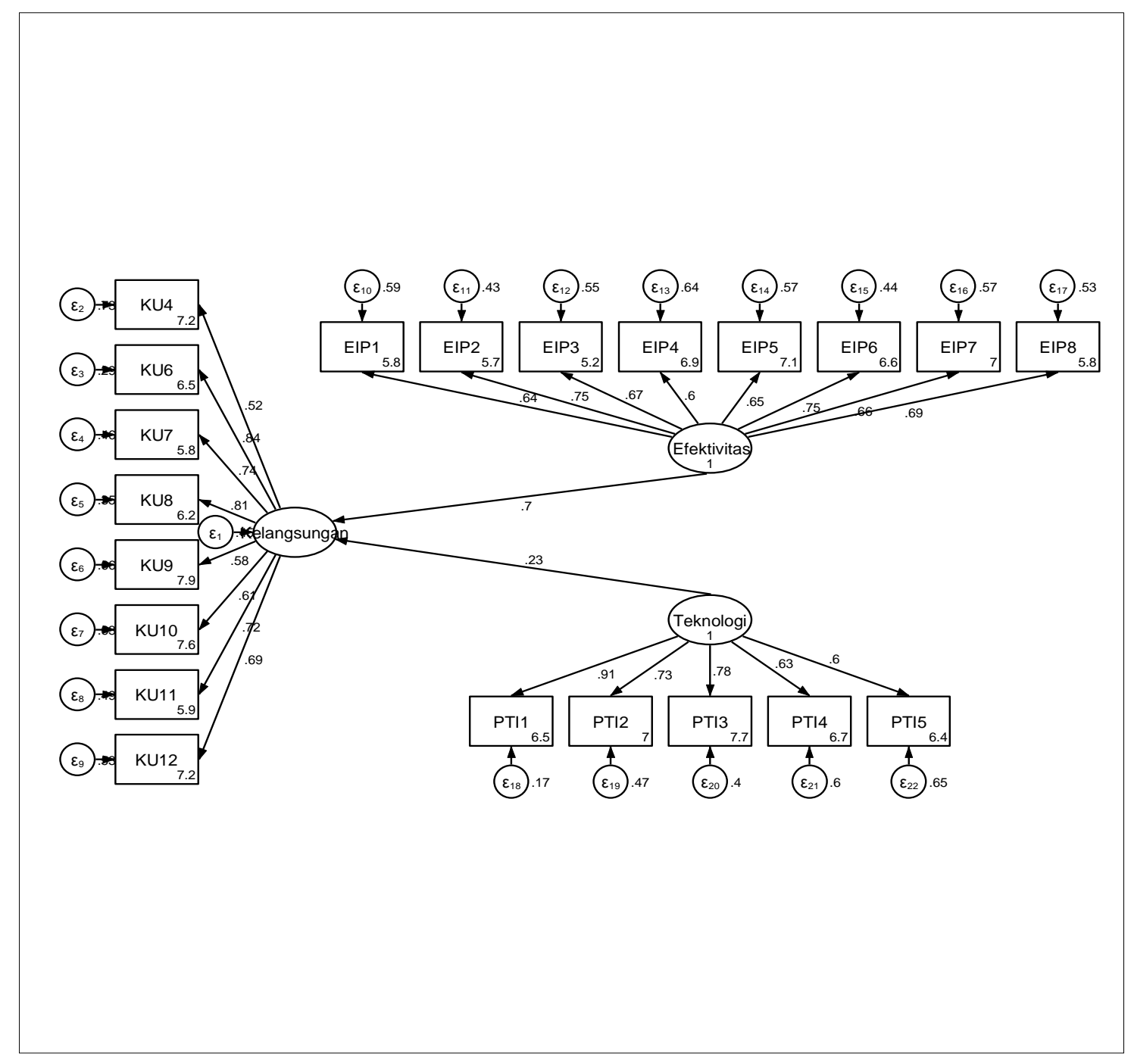

Tabel 9. Hasil Goodness Of Fit

\begin{tabular}{cccc}
\hline Kriteria & Hasil Goodness Of Fit & $\begin{array}{c}\text { Cut-off } \\
\text { Value }\end{array}$ & $\begin{array}{c}\text { Evaluasi } \\
\text { Model }\end{array}$ \\
\hline TLI & 0,72 & $\leq 90$ & Marginal Fit \\
CFI & 0,69 & $\leq 90$ & Marginal Fit \\
\hline
\end{tabular}

Sumber: data diolah (2020)

Hasil dari tabel menunjukan bahwa sudah terdapat salah satu yang sesuai dengan ciri-ciri dari goodness of fit yang dapat dikatakan telah memenuhi cut off value, artinya dapat dijelaskan hasil dari evaluasi tersebut telah menunjukan model yang sudah dapat diterima atau dikatakan baik. Hal ini telah menjelaskan bahwa suatu model yang dipakai dan digunakan pada penelitian telah menghasilkan dan mendapatkan tingkat perkiraan sesuai dengan harapan penulis. Maka model pada penelitian ini merupakan sebuah model yang dapat digunakan untuk mendeskripsikan hubungan antara tiap variabel yang ada pada model. Dengan melihat nilai Tucker-Lewis index/Non Normed Fit Index (TLI/NNFI), 0,72 
$\leq 0,90$ adalah marginal fit dan Comparative Fit Index (CFI) nilai CFI 0,69 $\leq 0,90$ juga merupakan marginal fit.

\section{Uji Hipotesis}

Pengujian pada hipotesis ini dilakukan untuk menguji penelitian mengenai ada atau tidaknya hubungan dan pengaruh antar variabel independen dengan variabel dependen. Standar atau aturan dari hasil dari pengujian apabila bisa menunjukan jika nilai dari probabilitas $\leq$ tingkat signifikansi (Alpha $=1 \%$ atau 0,01 ) hal ini dapat dinyatakan bahwa variabel independen mempunyai pengaruh yang signifikan terhadap variabel dependen. Dibawah ini dapat dilihat hasil dari pengujian pada hipotesis ini telah menggunakan aplikasi Stata 14 dan juga dapat dijelaskan pada ringkasan tabel berikut:

Tabel 10. Hasil Pengujian Hipotesis

\begin{tabular}{|c|c|c|c|c|c|}
\hline Hubungan & Dugaan & Estimate & $\mathbf{Z}$ & $\mathbf{P}$ & Keterangan \\
\hline $\begin{array}{l}\text { Efektivitas Insentif } \\
\text { Pajak } \rightarrow \text { Kelangsungan } \\
\text { UMKM Di Tengah COVID- } \\
19\end{array}$ & + & 0,70 & 21,18 & $0.00^{* * *}$ & Signifikan \\
\hline $\begin{array}{l}\text { Pemanfaatan Teknologi } \\
\text { Informasi } \rightarrow \text { Kelangsungan } \\
\text { UMKM Di Tengah COVID- } \\
19\end{array}$ & + & 0,23 & 5,22 & $0.00^{* * *}$ & Signifikan \\
\hline
\end{tabular}

Hasil dari pengujian hipotesis pertama yang dapat dilihat pada tabel 10 menunjukan bahwa variabel efektivitas insentif pajak berpengaruh positif terhadap kelangsungan UMKM di tengah pandemi COVID-19 yang ditunjukan dengan nilai estimate 0,70 dengan probabilitas sebesar 0,00, dimana nilai probabilitas tersebut lebih kecil dari $\alpha=1 \%$ atau 0,01 . Maka dapat disimpulkan bahwa efektivitas insentif pajak berpengaruh positif dan signifikan pada tingkat kepercayaan 99\% dalam mempertahankan kelangsungan UMKM di tengah pandemi COVID-19. Sehingga dapat dikatakan bahwa hipotesis 1 terpenuhi.

Pelaku UMKM merasakan adanya kemudahan dalam pengajuan untuk menerima insentif pajak PPh Final DTP, kemudahan dalam melaporkan pajaknya di masa pandemi COVID-19 dan kemudahan akses serta tidak adanya kendala baik dalam pengajuan atau pelaporan insentif pajak ini dapat mendorong para pelaku UMKM untuk memanfaatkan keringanan pajak atau insentif pajak yang diberikan oleh pemerintah dalam rangka menanggulangi dampak dari pandemi COVID-19.

Ketika para pelaku UMKM memanfaatkan insentif pajak ini akan memberikan impact positif karena insentif pajak ini dapat meringankan beban pelaku UMKM dalam hal perpajakan dimana pelaku UMKM tidak harus membayar ataupun dikenakan kewajiban pajak PPh Final sebesar 0,5\% dari peredaran brutonya sehingga dapat membantu meringankan pengeluaran pelaku UMKM di kondisi sulit akibat COVID-19 dan juga membantu kondisi keuangan para pelaku 
UMKM. Hal ini berarti efektivitas insentif pajak baik kemudahan yang dirasakan oleh pelaku UMKM dan impact positif yang ditimbulkan dari insentif pajak ini dapat mempertahankan kelangsungan UMKM di tengah pandemi COVID-19.

Hasil dari pengujian hipotesis pertama yang dapat dilihat pada tabel 10 menunjukan bahwa variabel pemanfaatan teknologi informasi berpengaruh positif terhadap kelangsungan UMKM di tengah pandemi COVID-19 yang ditunjukan dengan nilai estimate 0,23 dengan probabilitas sebesar 0,00 , dimana nilai probabilitas tersebut lebih kecil dari $\alpha=1 \%$ atau 0,01 . Maka dapat disimpulkan bahwa pemanfaatan teknologi informasi berpengaruh positif dan signifikan pada tingkat kepercayaan 99\% dalam mempertahankan dan meningkatkan kelangsungan UMKM di tengah pandemi COVID-19. Sehingga dapat dikatakan bahwa hipotesis 2 terpenuhi.

Memanfaatkan teknologi informasi di masa pandemi COVID-19 dapat membantu dan mempermudah pelaku UMKM dalam melakukan transaksi penjualan dan menjalankan berbagai kegiatan usahanya di masa pandemi. Pemanfaatan teknologi informasi ini didukung dengan adanya alat elektronik dan internet yang dapat diakses dan digunakan dimana pun, kapan saja dan oleh siapapun sehingga dapat mendorong berjalankan kegiatan usaha meskipun di kondisi sulit saat ini akibat pandemi COVID-19.

Berbagai kebijakan yang telah ditetapkan seperti Work From Home (WFH), Pembatasan Sosial Berskala Besar (PSBB) yang membatasi berbagai interaksi sosial dan dapat menghambat kegiatan usaha para pelaku UMKM, maka dengan memanfaatkan teknologi informasi ini mendukung pelaku UMKM untuk tetap menjalankan kegiatan usahanya dengan menggunakan situs penjualan, akun media sosial dan memanfaatkan layanan marketplace untuk melakukan berbagai promosi penjualan, berkomunikasi dengan konsumen dan melakukan transaksi penjualan ataupun mendistribusikan produknya sehingga kegiatan usaha di masa pandemi masih dapat berlangsung. Hal ini berarti dengan pemanfaatan teknologi informasi ini mampu mempertahankan kelangsungan UMKM di tengah pandemi COVID-19.

\section{SIMPULAN}

Kebijakan insentif pajak yang diberikan pemerintah memiliki tujuan untuk kelangsungan bisnis UMKM serta menjadi dukungan bagi para UMKM agar terus menjalankan kegiatan usahanya di masa pandemi dan hal ini sangat mendorong partisipasi dari para pelaku UMKM. Para pelaku UMKM mengapresiasi adanya kebijakan insentif pajak tersebut dengan pemanfaatan insentif pajak serta berusaha untuk meningkatkan kepatuhan akan perpajakannya. Insentif pajak ini dapat membantu dalam peningkatan kondisi keuangan bagi pelaku UMKM di masa pandemi karena pajak UMKM sudah ditanggung oleh pemerintah. Penelitian ini menguji semakin efektif pemberian insentif pajak maka dapat mempertahankan kelangsungan UMKM di masa pandemi COVID-19.

Teknologi informasi secara tidak langsung berpengaruh dan memiliki peranan besar dalam perkembangan bisnis online. Teknologi informasi memberikan cara untuk belajar layaknya di bisnis online, cara komunikasi, memberikan pandangan dan informasi tentang bisnis online sehingga pelanggan 
dapat dengan mudah dalam melakukan transaksi penawaran jual beli. Semakin tinggi tingkat pemanfaatan teknologi informasi maka mendukung pelaku UMKM untuk tetap menjalankan kegiatan usahanya dengan penggunaan situs penjualan, akun media sosial dan memanfaatkan layanan marketplace dapat mendukung berbagai promosi penjualan produknya, berkomunikasi dengan konsumen dan melakukan transaksi penjualan ataupun mendistribusikan produknya sehingga kegiatan usaha di masa pandemi masih dapat berlangsung tanpa adanya interaksi sosial secara langsung

Dalam penelitian selanjutnya diharapkan dapat menambahkan variabel bebas pada penelitian ini supaya dapat diketahui faktor lainnya yang berpengaruh kelangsungan UMKM di tengah pandemi COVID-19. Selain itu disarankan untuk mengambil sampel lebih banyak guna untuk keakuratan pada data yang lebih baik lagi.

Mempertahankan kelangsungan UMKM di tengah - tengah masa pandemi COVID-19. Hal ini mengandung implikasi bagi pemerintah dalam hal ini Direktorat Jenderal Pajak (DJP) semakin efektif insentif pajak yang diberikan oleh pemerintah dapat meningkatkan kelangsungan UMKM di masa pandemi dan meningkatkan kesadaran bagi para pelaku UMKM untuk membayar kewajiban perpajakannya. Pemanfaatan teknologi informasi dapat mempertahankan dan meningkatkan kelangsungan UMKM di tengah pandemi COVID-19. Hal ini mengandung implikasi bagi para pelaku UMKM bahwa teknologi menjadi faktor utama untuk setiap kegiatan di berbagai sektor usaha dengan menggunakan situs penjualan, akun media sosial dan memanfaatkan layanan marketplace pelaku UMKM dapat melakukan berbagai promosi penjualan, berkomunikasi dengan konsumen dan melakukan transaksi penjualan ataupun mendistribusikan produknya sehingga kegiatan usaha di masa pandemi dapat terus berjalan. Hal ini sangat penting untuk dimanfaatkan oleh pelaku UMKM.

\section{DAFTAR PUSTAKA}

News DDTC. (2020). Dipetik September 2020, dari Mengkaji Kebijakan Pengurangan Beban Pajak UMKM: https://news.ddtc.co.id

Pajak.go.id. (2020). Dipetik september 8, 2020, dari Sepenuh Hati Untuk UMKM Di Tengah Pandemi: www.pajak.go.id

Pajak.go.id. (2020). Dipetik September 8, 2020, dari DJP Jateng II imbau UMKM memanfaatkan Insentif Pajak: www.pajak.go.id

Indaryani, Mamik, Nita Indriyani Budiman, Sri Mulyani.;. (2020, Desember ). Dampak COVID-19 dan Pemanfaatan Insentif Pajak Terhadap Kelangsungan Usaha pada UMKM Tenun Troso Jepara. JURNAL MANAJEMEN DAN KEUANGAN, Vol. 9(No. 3), 76-86.

Kartiko, Nadis Dwi;. (2020, September 30). Insentif Pajak Dalam Merespon Dampak Pandemi COVID-19 Pada Sektir Pariwisata. Jurnal Pajak Dan Keuangan Negara, Vol. 11(No. 1), 124-137.

Khairiyah, Yotasa Ra'ida, Muhammad Heru Akhmadi;. (2019, November). Studi Kualitatif : Dampak Kebijakan Insentif Pajak Usaha Kecil Dan Menengah 
Terhadap Kepatuhan Pajak Dan Penerimaan Negara. Jurnal Manajemen Keuangan Publik, Vol.(No.), 36-45.

Kharisma, Raditha;. (2014). Pengaruh Pelaksanaan Peraturan Pemerintah Republik Indonesia Nomor 46 Tahun 2013 Tentang Pajak Penghasilan Terhadap Kelangsungan Usaha Mikro Kecil Dan Menengah (UMKM). Skripsi. Jember: Universitas Jember.

Perdani, Kadek Kusuma, I Gst Ayu Eka Damayanthi;. (2017, Juni). Pengaruh Pemanfaatan Teknologi, Partisipasi Pemakai, Manajemen Puncak Dan Kemampuan Pemakai Terhadap Efektivitas Sistem Informasi Akuntansi. Jurnal Akuntansi Universitas Udayana, Vol. 19(No. 3), 2234-2261.

Priambada, Swasta;. (2015). Manfaat Penggunaan Media Sosial Pada Usaha Kecil Menengah (UKM). 43-46.

Prof. Dr. H. Siswoyo Haryono, MM, MPd;. (2015). Metode SEM Untuk Penelitian Manajemen dengan AMOS, LISLER dan PLS (62-81 ed.). Yogyakarta.

Rachmawati, N. A., \& Ramayanti, R. (2016). Manfaat Pemberian Insentif Pajak Penghasilan dalam Kepatuhan Wajib Pajak UMKM. Jurnal Akuntansi, Ekonomi dan Manajemen Bisnis, 4 (2), 176-185.

Rahayu, Nurulita;. (2017, April). PENGARUH Pengetahuan Perpajakan, Ketegasan Sanksi Pajak, Dan Tax Amnesty Terhadap Kepatuhan Wajib Pajak. Jurnal UST JOGJA, Vol. 1(No. 1), 15-30.

Republik Indonesia, Peraturan Pemerintah Nomor 23 Tahun 2018 Tentang Pajak Penghasilan Dari Usaha Yang Diterima Atau Diperoleh Dari Wajib Pajak Yang Memiliki Peredaran Bruto Tertentu.

Republik Indonesia, Peraturan Menteri Keuangan Nomor 110 Tahun 2020 Tentang Insentif Pajak Untuk Wajib Pajak Terdampak Coronavirus Disease 2019.

Republik Indonesia, Peraturan Menteri Keuangan Nomor 23 Tahun 2020 Tentang Insentif Pajak Untuk Wajib Pajak Terdampak Wabah Virus Corona.

Republik Indonesia, Peraturan Menteri Keuangan Nomor 44 Tahun 2020 Tentang Insentif Pajak Untuk Wajib Pajak Terdampak Coronavirus Disease 2019.

Republik Indonesia, Peraturan Menteri Keuangan Nomor 86 Tahun 2020 Tentang Insentif Pajak Untuk Wajib Pajak Terdampak Coronavirus Disease 2019.

Republik Indonesia, Peraturan Pemerintah Nomor 23 Tahun 2018 Tentang Pajak Penghasilan Dari Usaha Yang Diterima Atau Diperoleh Dari Wajib Pajak Yang Memiliki Peredaran Bruto Tertentu.

Republik Indonesia, Peraturan Undang-Undang Nomor 24 Tahun 2007 Tentang Penanggulangan Bencana.

Republik Indonesia, Undang-Undang Nomor 20 Tahun 2008 Tentang Usaha Mikro, Kecil, dan Menengah.

Salamah, Irma , RD Kusumanto, M. Aris Ganiardi;. (2016, Februari). Analisis Faktor-Faktor Yang Mempengaruhi Penggunaan Sistem Informasi Pada Tiga Ukm Industri Kain Tenun Songket Kota Palembang. Vol. 1(No. 4), 13-16.

Sari, Rafika;. (2018, Juni). Kebijakan Insentif Pajak Bagi Usaha Mikro, Kecil dan Menengah. Vol. 10(No. 12), 19-24.

Sudrajat, Ajat, Arles Parulian Ompusunggu; (2015, Desember). Pemanfaatan teknologi Informasi, Sosialisasi Pajak, Pengetahuan Perpajakan, dan Kepatuhan Pajak. Jurnal Riset Akuntansi dan Perpajakan, Vol. 2(No. 2), 193 202. 
Sugiri, Dani;. (2020, Juli 31). Menyelamatkan Usaha Mikro, Kecil dan Menengah Dari Dampak Pandemi COVID-19. Media Pengkajian Manajemen dan Akuntansi, Vol. 19(No. 1).

Utami, Setyaningsih Sri;. (2010, April). Pengaruh Teknologi Informasi Dalam Perkembangan Bisnis. Jurnal Akuntansi dan Sistem Teknologi Informasi, Vol. 8(No. 1), 61-67. 